\title{
Biological activities of limonoids in the Genus Khaya (Meliaceae): a review
}

\author{
Tomi Lois Olatunji ${ }^{1}$, Christiana Adeyinka Odebunmi ${ }^{2}$ and Ademola Emmanuel Adetunji ${ }^{3^{*}}$ (D)
}

\begin{abstract}
Background: Limonoids are a class of highly oxygenated modified triterpenoids with a diverse range of biological activities. Although with restricted occurrence in the plant kingdom, these compounds are found extensively in the Meliaceae and Rutaceae families. Limonoids are of great interest in science given that the small number of plant families where they occur exhibit a broad range of medicinal properties that promote health and prevent disease.

Main text: The Meliaceae family includes the genus Khaya and comprises tree species that have been used in traditional medicine to treat several ailments. In recent years, the genus Khaya has attracted much research interest owing to the presence of limonoids in different plant parts of a few species that can serve as therapeutic molecules in the pharmaceutical industry. In this study, a literature search over the past two decades (2000-2020) was conducted on the biological activities of limonoids in the genus Khaya using different databases such as Google Scholar, PubMed, Scopus and ISI Web of Science. The taxonomy, geographical distribution and the various traditional uses of the genus are presented in detail. This study reveals that the currently documented biological activities of limonoids both in vivo and in vitro are limited to four species (K. anthotheca, K. grandifoliola, K. ivorensis and $K$. senegalensis) in the genus Khaya, and include anticancer, antimalarial, hepatoprotection, anti-inflammatory, neuroprotection, antimicrobial, antifungal and antifeedant. The most well-researched species, K. senegalensis, has the most notable biological activities and traditional uses in the genus Khaya.

Conclusion: The present detailed and up-to-date review of recent literature on the biological activities in the genus Khaya reveals the potentials of limonoids for drug development in managing several ailments.
\end{abstract}

Keywords: Biological activities, Diseases, Drug development, Khaya, Limonoids, Meliaceae

\section{Background}

Natural compounds from plants are continually investigated to discover new therapeutics in treating and preventing several human ailments [1]. Historically, medicinal plants have been efficient as a remedy for several ailments [2] and thus form an integral aspect of traditional medicines and various science fields [3]. As listed by the World Health Organization (WHO), there are up to 20,000 medicinal plants in 91 different countries worldwide [4]. Many of these plants have been evaluated and documented for potency and remedial capabilities

\footnotetext{
* Correspondence: adetunjiademola@hotmail.com

${ }^{3}$ School of Life Sciences, University of KwaZulu-Natal, Durban 4001, South Africa

Full list of author information is available at the end of the article
}

[5-7]. Research intensification in natural products derived from medicinal plants as a source of new drugs is mainly due to the plants abundant biologically active compounds (secondary metabolites) which have become central components in modern therapy [8]. These broad-range bioactive secondary metabolites are present in different plant organs such as fruits, stem, bark, leaves, seeds and roots [7], and are structurally and functionally diverse, thereby providing various prospects for developing novel drug leads in the pharmaceutical industry [4].

Among the plant secondary metabolites of significant importance are the limonoids, which are primarily found in the Meliaceae and Rutaceae (citrus) families and occur less frequently in Simaroubaceae and Cneoraceae 
families $[9,10]$. In addition to their abundance, limonoids present in the family Meliaceae often referred to as meliacins, are of unique interest due to their structurally diverse and highly potent activity with relevant biological properties than those found in other families [2, $11,12]$. Interestingly, the genus Khaya (commonly known as African Mahogany) belonging to the family Meliaceae, is highly reputed for several biological activities that are attributed to limonoids present in different plant parts of different species [13]. On account of their extensive range of biological activities, including anticancer [14-16], antimalarial $[17,18]$, anti-inflammatory $[16$, 19], antifeedant [20, 21] among others, limonoids are increasingly gaining research interest.

There have been recent individual studies in Khaya species, mostly focusing on the plant extracts bioactivities and the composition of the constituents in various plant parts. However, to our knowledge, no study which presents all reported bioactivities with a focus on limonoids has been documented in the genus Khaya despite the significance of limonoids within the genus. Hence, the present review of recent literature aimed to present in-depth and current reports on the biological activities of limonoids in the different Khaya species and their significance in developing new therapeutics for different human ailments.

A literature search on the biological activities of limonoids in the genus Khaya was performed using different databases such as Google Scholar, PubMed, Scopus and ISI Web of Science. The literature search was limited to articles and other relevant materials over the past two decades (from 2000 to 2020) to present current studies in this review. Free, full-text articles available in English were used for the review, focusing mainly on the four species (K. anthotheca, K. grandifoliola, K. ivorensis and $K$. senegalensis) in the genus Khaya where limonoids have been reported. All chemical structures were drawn with ChemDraw Ver. 19.1 (PerkinElmer Inc., Waltham, USA).

\section{Main text}

\section{The genus Khaya at a glance}

The genus Khaya belongs to the mahogany family Meliaceae comprising several economically important tree species, including Toonia ciliata, Azadirachta indica, Switetenia macrophylla, Cedrella odorata [22] and all Khaya species [23]. The genus Khaya consists of six recognized species: $K$. anthotheca (Welw.) C.DC., K. grandifoliola C.DC., K. ivorensis A. Chev., K. senegalensis (Desr.) A. Juss, K. madagascariensis Jum. \& H.Perrier and K. nyasica Staph ex Baker f. [24], that are of high commercial and economic importance. The species of Khaya are native to Madagascar and tropical Africa and have been introduced to Southern Asia and Australia from central Africa [25]. In their natural distributions, Khaya species are esteemed for timber, therapeutic products and attractiveness [22]. Khaya species have similar fruits and flowers, and the most apparent differences are seen in their leaflets. The scientific classification of Khaya species is presented in Fig. 1.

\section{Khaya anthotheca: description and distribution}

Khaya anthotheca, commonly known as East African Mahogany, is a large evergreen tree species native to tropical Africa [26]. The specific name anthotheca is derived from two Greek words, "anthos" and "theca" meaning flower and capsule, respectively. Khaya anthotheca is fast growing and grows up to $60 \mathrm{~m}$ in height $(30 \mathrm{~m}$ in gardens) [23]. The leaves are spirally arranged, alternate, with 3-7 leaflets and dark-glossy green in colour. The bark of the tree is greyish brown. Stipules are absent, and the petiole is $3.5-7 \mathrm{~cm}$ long. The inflorescence is axillary with panicle that is $30-40 \mathrm{~cm}$ long and flowers are unisexual. The fruits are erect, nearly globose with woody capsules that are $4-10 \mathrm{~cm}$ in diameter, dehisce into 4-5 halves with many seeds [23]. Seeds are diskshaped or quadrangular [23]. Khaya anthotheca is found at low to medium altitudes in riverine fringe and evergreen forests in Africa [27]. It occurs widely in Guinea Bissau east, Angola, Uganda, Zambia, Zimbabwe, Tanzania and Mozambique. It has been grown successfully in Cuba, the eastern part of South Africa, Puerto Rico, tropical America and tropical Asia [27].

\section{Khaya grandifoliola: description and distribution}

Khaya grandifoliola commonly referred to as the large-leaf mahogany is a medium-large tree that grows up to $40 \mathrm{~m}$ in height and usually deciduous in dry seasons [28]. It is monoecious, and leaves are often arranged spirally with cluster ends, paripinnately compound with 3-5 leaflets in pairs. The flowers are unisexual, and the male and female flowers are much alike. The fruits are erect with woody capsules that are $6-9 \mathrm{~cm}$ in diameter, globose and dehisce by five halves with many seeds. Seeds are brown, flat and disk-shaped [28]. Khaya grandifoliola occurs naturally in the fringe between rain forest and the drier parts of savanna and occurs widely in western tropical Africa from Guinea-Bissau to Sudan and Uganda [29]. It is found in Nigeria, Benin, Congo, Sudan, Ghana, Togo, Ivory Coast and Uganda [28].

\section{Khaya ivorensis: description and distribution}

Khaya ivorensis, commonly known as Lagos Mahogany or heavy African mahogany, is a tall evergreen forest tree (occasionally deciduous in drier climates) with a large buttressed trunk [30]. Like other species in its genus, $K$. 


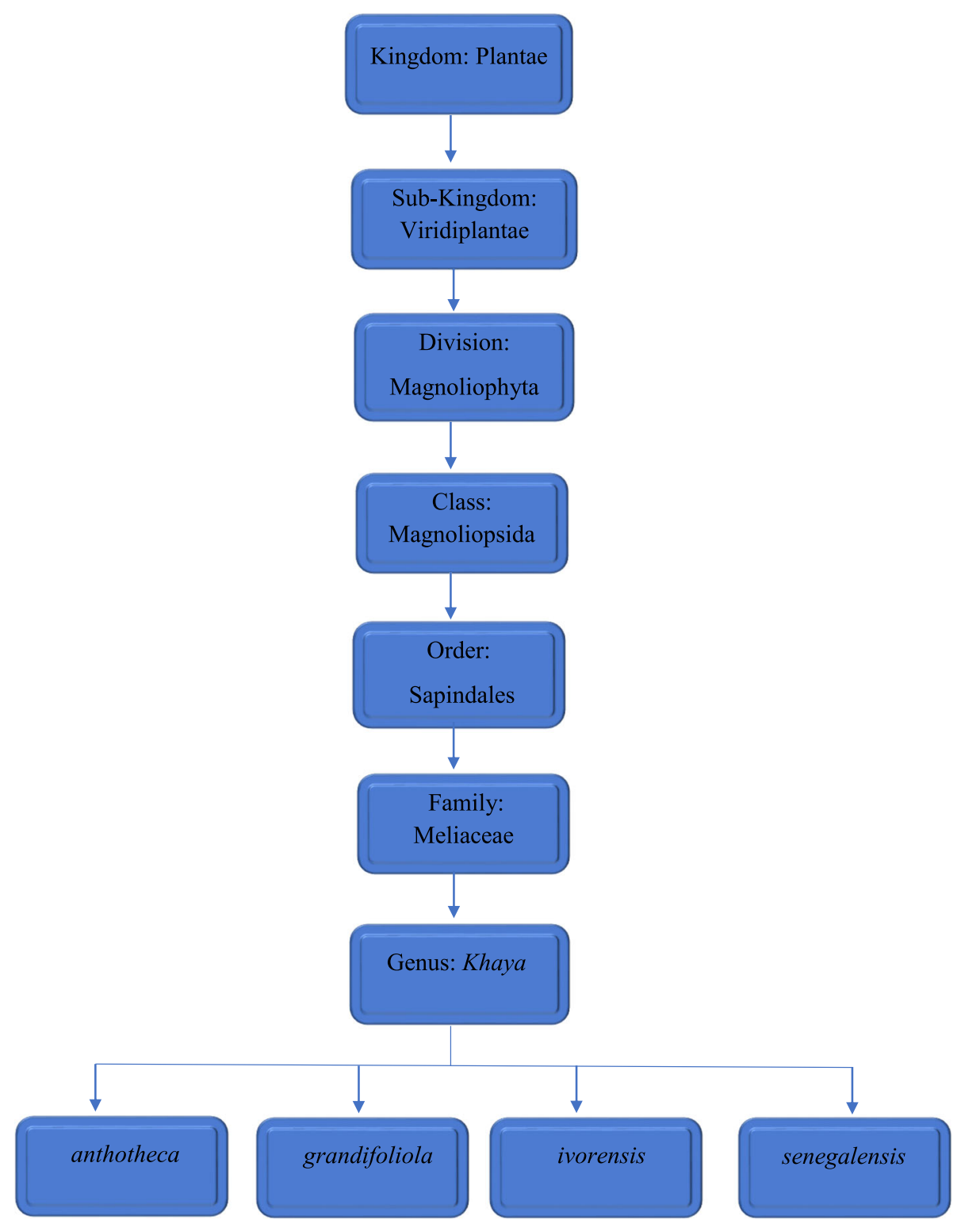

Fig. 1 Scientific classification of Khaya species

ivorensis grows up to $40-50 \mathrm{~m}$ in height. The leaves are compound, broad and are spirally arranged with 3-7 leaflets. The inflorescence is an axillary panicle which grows up to $20 \mathrm{~cm}$ long. The flowers are unisexual with a striking resemblance between the male and the female flowers. Fruits are greyish brown, erect with a woody capsule and are many-seeded [30]. The seeds are brown, disk-like shaped and flat. Khaya ivorensis occurs most abundantly in the evergreen forest. It is indigenous to Africa and naturally distributed from Sierra Leone and Liberia to Gabon [27]. It is found in Angola, Cameroon, Ghana, Ivory Coast and Nigeria and has been fairly grown in some plantations of tropical America and Asia.

\section{Khaya senegalensis: description and distribution}

Khaya senegalensis is commonly referred to as dry zone or Senegal mahogany [31]. It is an evergreen, mediumsized tree that grows up to $15-30 \mathrm{~m}$ in height and $1 \mathrm{~m}$ in diameter. In its natural distribution, K. senegalensis is usually grown as a roadside and ornamental shade tree [32]. The leaves are paripinnately compound, with leaflets in pairs of 2-6, spirally arranged but are clustered close to the end of branches. The flowers are regular, unisexual, sweet-scented and white. The fruits are palegrey to greyish brown, erect, with a woody capsule of 4$6 \mathrm{~cm}$ in diameter and highly seeded. The fruit dehisces into four halves. The seeds are brown, quadrangular in 
shape and are flat. Khaya senegalensis is naturally found in savanna woodland, usually in a wet area with an annual rainfall of $650-1800 \mathrm{~mm}$ [32]. The tree is native to Senegal, Nigeria, Ghana, Benin, Mali, Sudan, Togo, Gambia, Burkina Faso, Uganda, Ivory Coast, Cameroon, Niger and Guinea-Bissau. It has been successfully grown in South Africa, Malawi, India, Vietnam, Madagascar, Australia, Egypt, Indonesia and tropical America [22].

\section{Uses of Khaya species in traditional medicine}

Khaya species, which are timber trees in the family Meliaceae, have been used traditionally for treating several ailments (Table 1), including malaria, rheumatism, fever and back pain in Africa [19]. The crude extracts from different parts of these tree species have been reported to exhibit anti-inflammatory [19], antioxidative and anti-diabetic [13] and anti-hypertensive [44] activities among others, which justify their traditional use in the treatment of some ailments.

\section{Limonoids in the genus Khaya}

The word "limonoid" was derived from limonin more than a century ago when researchers isolated a primary bitter principle (limonin) in citrus seeds [9]. Limonoids are a class of highly oxygenated modified triterpenoids that exist extensively in the Meliaceae and Rutaceae plant families [45], and less frequently in Simaroubaceae and Cneoraceae families. Occasionally, limonoids have been reported in some species of the families Euphorbiaceae, Burseraceae, Boraginaceae and Flacourtiaceae, implying that these important secondary metabolites may be more varied and extensively spread than initially thought [11] (Figs. 2, 3, 4 and 5).

Structurally, limonoids are derived from triterpene by the loss of four carbon atoms from a side chain of apoeuphane or apotirucallane skeleton, forming $17 \beta$ furan ring after cyclization $[2,10]$. Hence, they are alternatively regarded as tetranortriterpenoids [45] and are classified by an intact ring system and those in which one of the four rings (A, B, C, or D) has been oxidized [46]. Limonoids are of great interest in science given that

Table 1 Uses of Khaya species in traditional medicine

\begin{tabular}{|c|c|c|c|c|}
\hline Ailment & Khaya species & Part used & Country & References \\
\hline Rheumatism & K. ivorensis & Bark & Nigeria & [33] \\
\hline Fever & K. grandifololia & Stem bark & Nigeria & [33] \\
\hline Pile & K. senegalensis & Bark & Nigeria & [33] \\
\hline \multirow[t]{4}{*}{ Malaria } & K. grandifololia & Leaves & Cameroon, & [34] \\
\hline & K. senegalensis & Seeds & Cameroon & [34] \\
\hline & & Leaves & Togo & [35] \\
\hline & K. senegalensis & Bark & Burkino-Faso & {$[31]$} \\
\hline \multirow[t]{2}{*}{ Anaemia } & K. ivorensis & Bark & Nigeria & {$[36]$} \\
\hline & K. senegalensis & Bark & Burkino-Faso & [31] \\
\hline Nervous system and mental disorder & K. senegalensis & Bark & Ghana & [37] \\
\hline Liver problem & K. grandifololia & Stem bark & Cameroon & {$[38]$} \\
\hline Worm infestations & K. anthotheca & Bark & Madagascar & [39] \\
\hline Microbial infections & K. anthotheca & Bark & Madagascar & [39] \\
\hline \multirow[t]{3}{*}{ Diarrhoea } & K. anthotheca & Leaves & Madagascar & {$[40]$} \\
\hline & K. senegalensis & Bark & Burkino-Faso & [31] \\
\hline & & Stem bark & C'ote-d'Ivoire & [41] \\
\hline Haemorrhoids & K. senegalensis & Root & Togo & {$[35]$} \\
\hline Epilepsy & K. senegalensis & Stem bark & Togo & {$[35]$} \\
\hline Boil & K. senegalensis & Bark & Mali & {$[42]$} \\
\hline Hypertension & K. senegalensis & Stem bark & Togo & {$[35]$} \\
\hline Diabetes & K. senegalensis & Stem bark & Togo & {$[35]$} \\
\hline \multirow[t]{2}{*}{ Wounds } & K. senegalensis & Stem bark & C'ote-d'Ivoire & [41] \\
\hline & K. senegalensis & Bark & Mali & [42] \\
\hline Snake/insect bite & K. senegalensis & Bark & Mali & {$[42]$} \\
\hline Sexually transmitted infections & K. senegalensis & Stem bark & Guinea & [43] \\
\hline
\end{tabular}



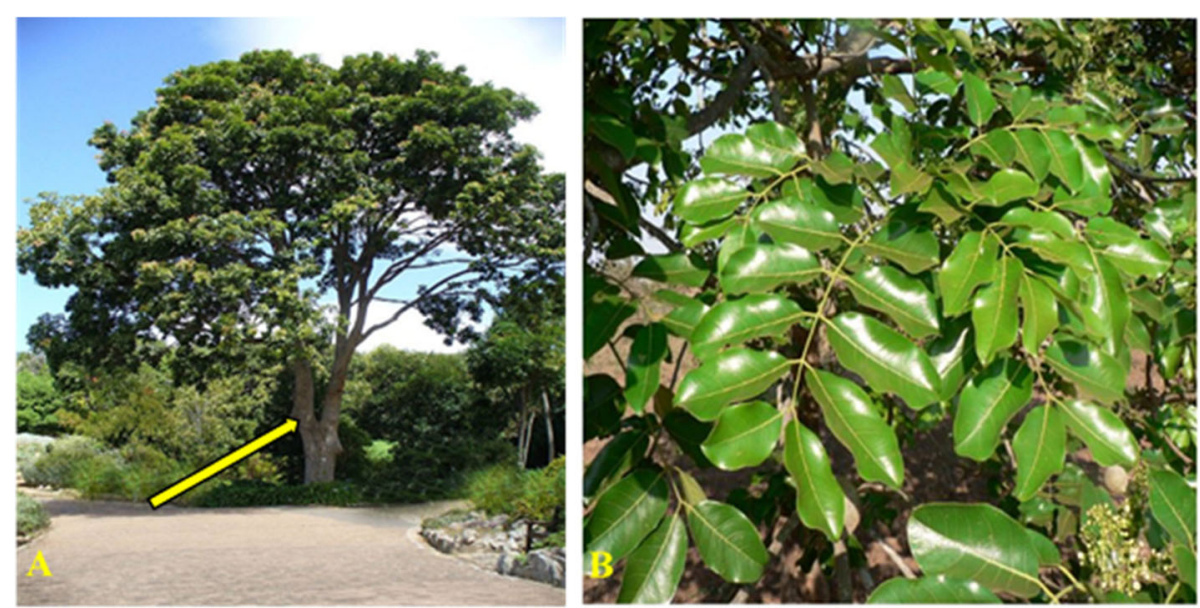

Fig. 2 K. anthotheca. a Tree. b Leaves. Source: Google images

the small number of plant families where they occur exhibit a broad range of biological activities that promote health and prevent disease.

Several chemical investigations have revealed that the genus Khaya is highly characterized by abundant, structurally diverse and biologically active rings D, B, D-Seco limonoids like gedunins, mexicanolide, phragmalin and andirobins in various parts of the tree, mainly the stem bark (Figs. 6, 7, 8 and 9). For instance, [50] isolated six new limonoids (khayasenelide A-F) in addition to six known limonoids (1-O-deacetyl-2 $\alpha$-hydroxykhayanolide E, 1-O-deacetylkhayanolide E, senegalensions A, khayanolide $B$, khaysenegain $E$ and khaysenegain I) from the stem bark of $K$. senegalensis [47] isolated two new limonoids (14,15-didehydroruageanin $\mathrm{A}$ and 3-Omethylbutyrylseneganolide A) from the fruits of $K$. ivorensis. From the stem bark of K. anthotheca, [48] isolated four new limonoids namely anthothecanolide, 3-Oacetylanthothecanolide, 2,3-di-O-acetylanthothecanolide and $6 \mathrm{R}, 8 \alpha$-dihydroxycarapin. In another study, three limonoids (17-epi- methyl-6-hydroxyangolensate, 7deacetoxy-7-oxogedunin and 7-deacetoxy-7R-hydroxygedunin), with hepatoprotective activity, were isolated from the stem bark of K. grandifoliola [49].

\section{Biological activities of limonoids in the genus Khaya Anticancer activity}

Globally, cancer in whichever form is one of the leading causes of mortality. In the next two decades, it is estimated to increase by about $70 \%$ worldwide with the most significant impact on low income and developing countries [51]. Several efforts such as surgery, chemotherapy and radiotherapy have been used in the fight against cancer in the past few decades. However, cancer
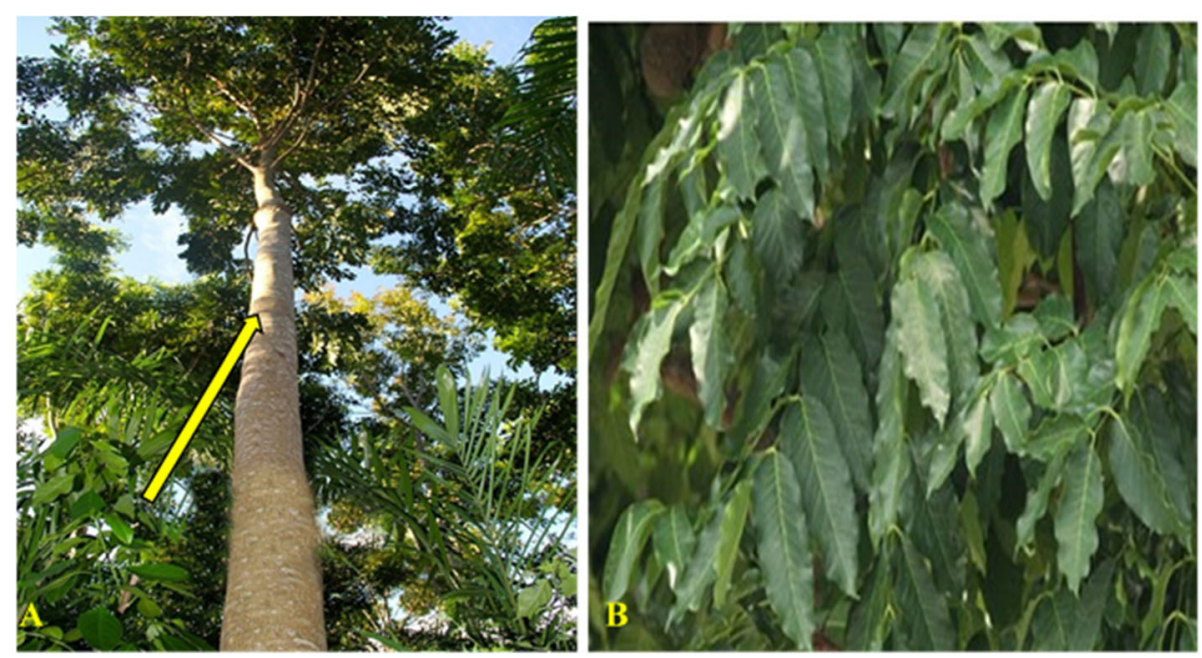

Fig. 3 K. grandifoliola. a Tree. b Leaves. Source: Google images 

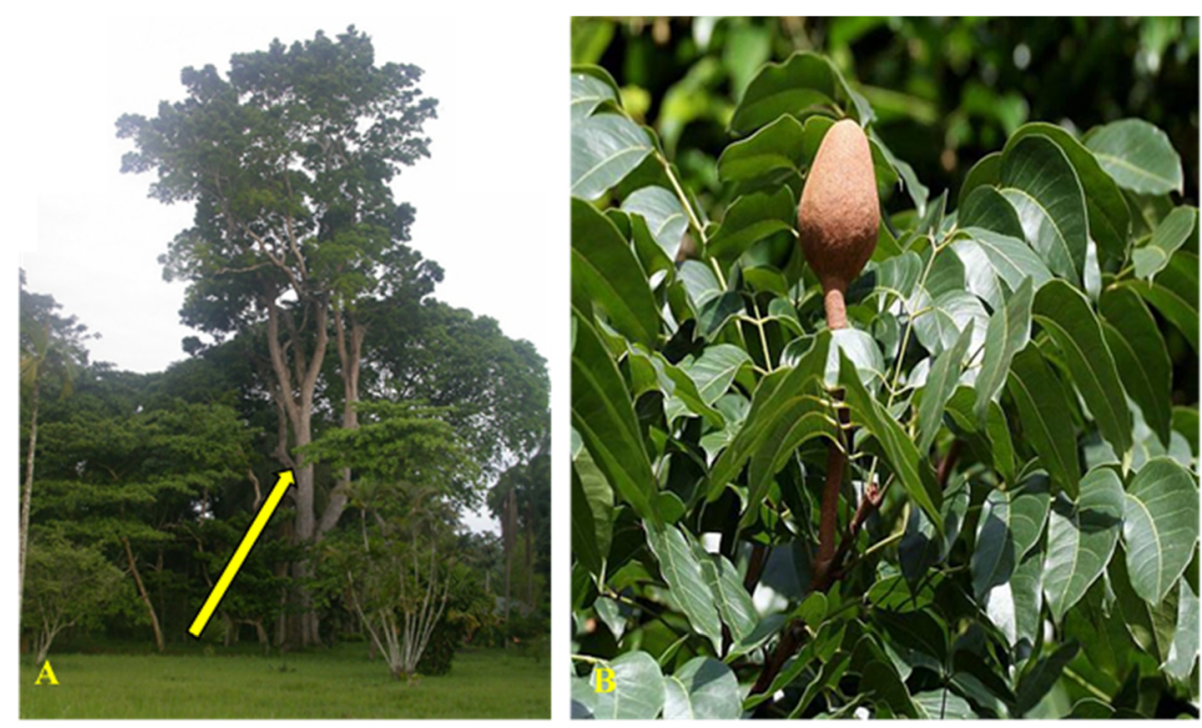

Fig. 4 K. ivorensis. a Tree. b Leaves. Source: Google images

treatment remains a significant challenge owing to tumour diversity, damage to normal cells, resistance and recurrence of tumours even after years of remission [52].

Studies have indicated that bioactive compounds in medicinal plant extracts with anticancer potentials are currently attracting researchers' attention in the fight against cancer. Verma et al. [15] examined the inhibitory capability and mechanism of action of anthothecol, a limonoid from $K$. anthotheca and anthothecol encased poly (D,L-lactic-co-glycolic acid) nanoparticles (AnthoNPs) on pancreatic cancer stem cells and cell lines obtained from human and Kras ${ }^{\mathrm{GI} 2 \mathrm{D}}$ mice.

The study established that anthothecol and antho-NPs repressed the spread of cancer stem cells and cell lines in a dose-dependent form without affecting the normal human pancreatic ductal epithelial cells. Additionally, anthothecol alone and antho-NPs were reported to cause apoptosis on pancreatic stem cells and cell lines and prevented colonies formed by cancer cells in a dosedependent manner. The study reported that antho-NPs prevented the expression of pluripotency maintaining factors (cMyc and Nanog) and hindered self-renewing ability of stem cell markers (CD44 and CD24) in pancreatic cancer stem cells. Similarly, in pancreatic cancer stem lines isolated from human and $\mathrm{Kras}^{\mathrm{GI} 2 \mathrm{D}}$ mice, antho-NPs inhibited pancreatic cancer stem cells' growth by hindering spheroids' cell viability. Also, in a dosedependent manner in the pancreatic cancer stem cells and cell lines, antho-NPS inhibited epithelialmesenchymal transition (a key driver of metastasis) and
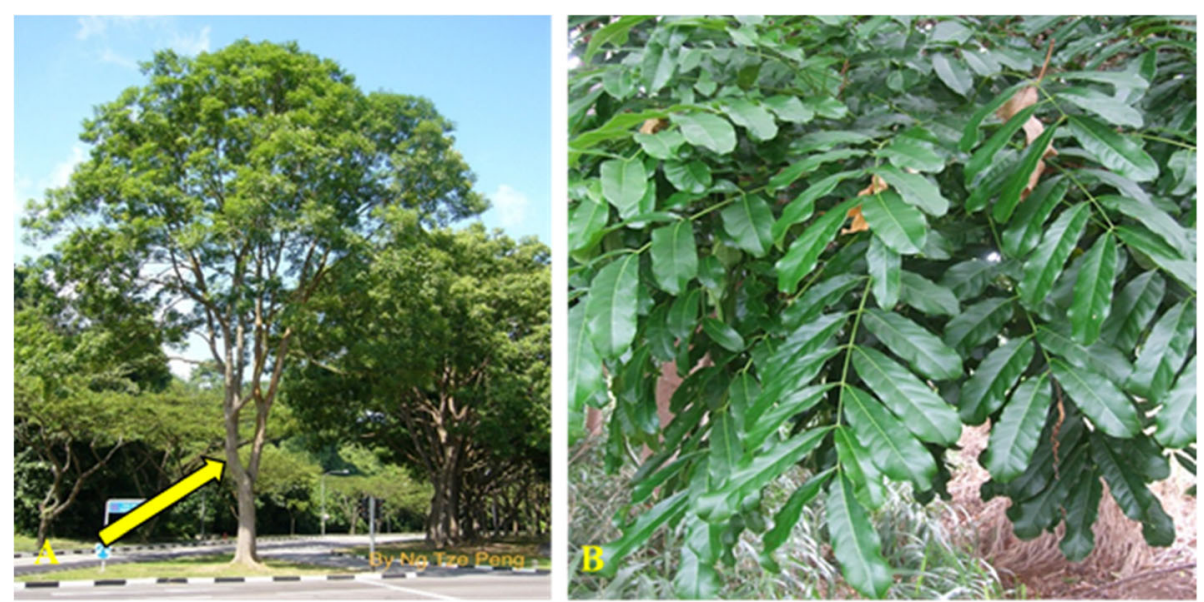

Fig. 5 K. senegalensis. a Tree. b Leaves. Source: Google images 

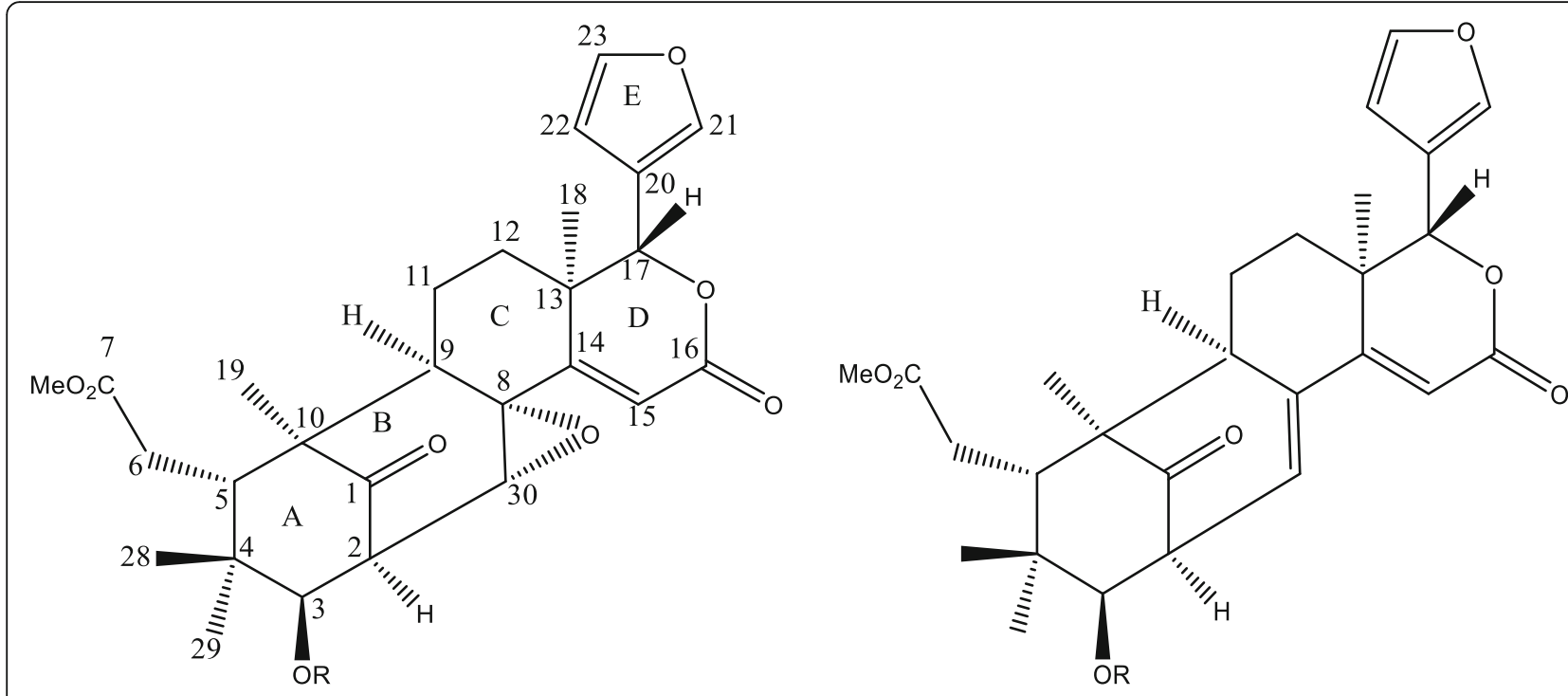

1

2

Fig. 6 Structure of limonoids from the fruits of K. ivorensis (1) 14,15-didehydroruageanin A and (2), 3-O-methyl-butyrylseneganolide A. Adapted from [47]

hindered the expression of sonic hedgehog signaling pathway that leads to the production of tumours. The results suggest that anthothecol and antho-NPs are potent in preventing and treating human pancreatic cancer. The mechanism via which antho-NPs caused inhibition of cell proliferation of pancreatic cancer stem cells and cell lines was attributed to the disruption of Gli-DNA binding activity.

In another study by [14], the antitumor activity of a limonoid ( $3 \alpha, 7 \alpha$-dideacetylkhivorin) obtained from the methanol extract of the stem bark of $K$. senegalensis was examined on human breast (MCF-7), colon
(Caco-2) and cervical (SiHa) cancer cell lines. They reported that $3 \alpha, 7 \alpha$-dideacetylkhivorin, in a dosedependent manner, prevented the proliferation of MCF-7, Caco-2 and SiHa cell lines. The highest concentration examined (200 ppm) prevented 66\%, $70 \%$ and $61 \%$ cell growth for MCF-7, Caco-2 and $\mathrm{SiHa}$, respectively. Further, the $\mathrm{IC}_{50}$ values leading to inhibition of cell proliferation were reported as 0.14 $\mu \mathrm{M}, 0.07 \mu \mathrm{M}$ and $0.11 \mu \mathrm{M}$, for MCF-7, Caco- 2 and $\mathrm{SiHa}$, respectively. The results suggest that $3 \alpha, 7 \alpha-$ dideacetylkhivorin is a potent anticancer agent against several human cancers.
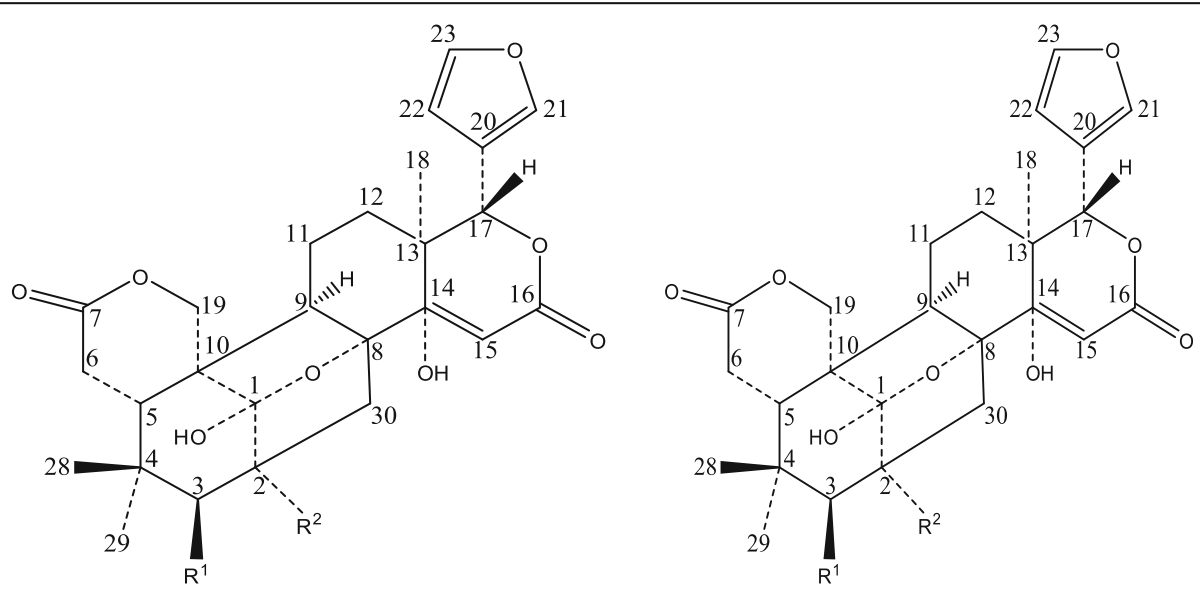

3

4

Fig. 7 Structure of limonoids from the stem bark of $K$. anthotheca (3) 3-O-acetylanthothecanolide. $\mathrm{R}^{1}=\mathrm{OH}, \mathrm{R}^{2}=\mathrm{OH}$. (4) 2,3-di-Oacetylanthothecanolide. $\mathrm{R}^{1}=\mathrm{OA}_{\mathrm{C}}, \mathrm{R}^{2}=\mathrm{OH}$. Adapted from [48] 


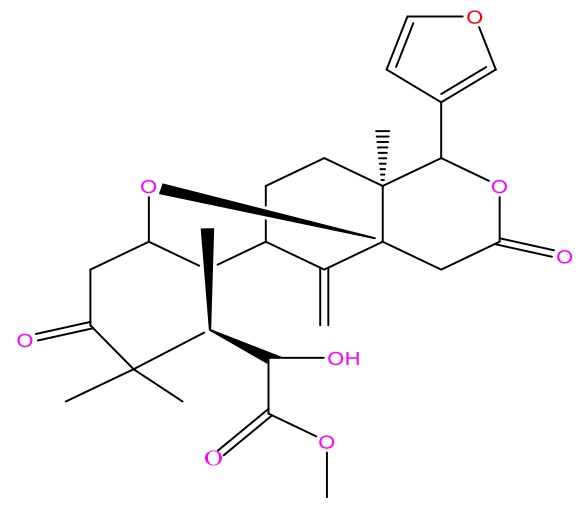

5

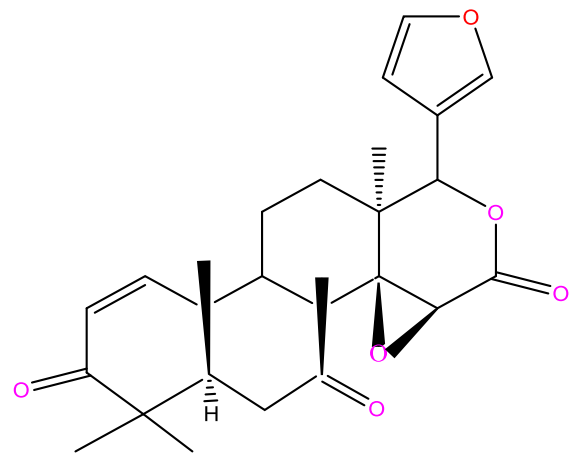

6

Fig. 8 Structure of limonoids from the stem bark of K. grandifoliola (5) 17-epi-methyl-6-hydroxyangolensate. (6) 7-deacetoxy-7-oxygedunin. Adapted from [49]

As reported by [16], in vitro cytotoxicity screening of khayasenelide G, a limonoid isolated from the stem bark of $K$. senegalensis evaluated against human cancer cell lines (MDA-MB-231 and HepG2), showed effective cytotoxicities against the tumour cell lines with $\mathrm{IC}_{50}$ values of 6.02 and $8.98 \mu \mathrm{M}$, respectively.

In vitro cytotoxic activity of different extracts of $K$. grandifoliola leaves was evaluated on liver carcinoma (HEPG2), breast carcinoma (MCF7), cervix carcinoma (HELA), larynx carcinoma (HEP2) and colon carcinoma (HCT116) cell lines by [25]. The authors revealed that the ethanolic leaf extract of $K$. grandifoliola exhibited cytotoxic effects against HEPG2, MCF7 HEP2 and HCT116 carcinoma cell lines and the results were comparable to the effects exhibited by the standard (doxorubicin) while the chloroform extract showed high toxicity effects against HCT116 only. These cytotoxic effects of $K$. grandifoliola leaf extracts were attributed to two isolated limonoids $\beta$-sitosterol-3-O- $\beta$-D-glucopyranoside and $\beta$-stigmasterol-3-O- $\beta$-D-glucopyranoside in the chloroform extract.

Additionally, a study conducted by [47] on the cytotoxic activity of limonoids from the fruit of $K$. ivorensis against five cancer cell lines, revealed that some limonoids showed cytotoxicity against the cancer cell lines. Three limonoids (3-O-methyl-butyrylseneganolide A, seneganolide $\mathrm{A}$ and 1,3-dideacetylkhivorin) demonstrated cytotoxicity against lung cancer (A-549), myeloid leukaemia (HL-60), hepatocellular carcinoma (SMMC7721), colon cancer (SW480) and breast cancer (MCF-

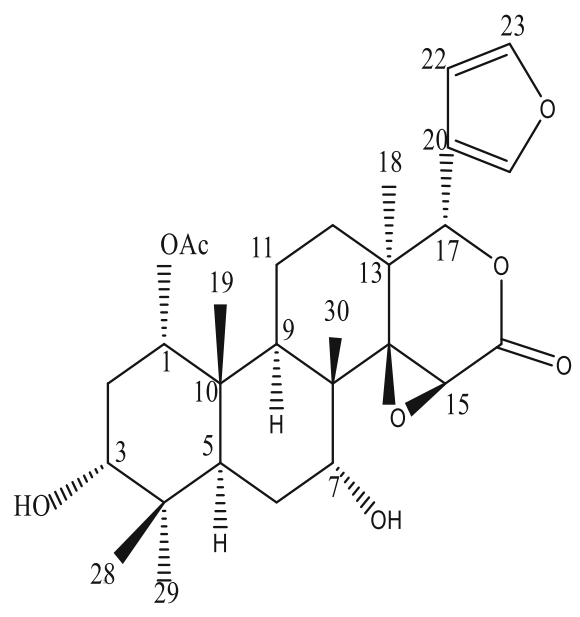

7

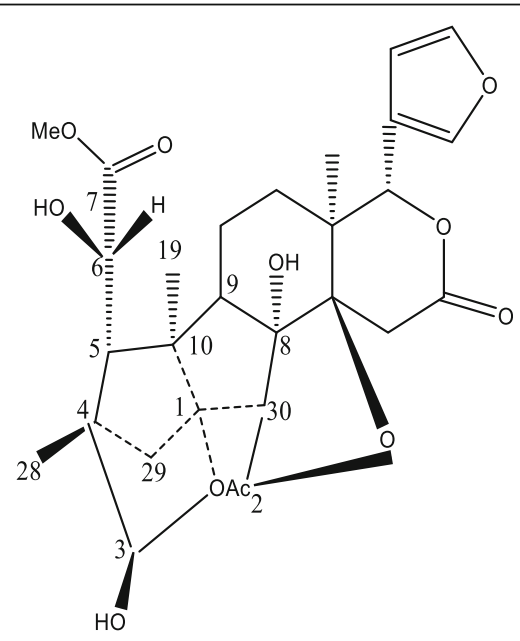

8

Fig. 9 Structure of limonoids from the stem bark of K. senegalensis. (7) 3a, 7a-dideacetylkhivorin. (8) 1-O-acetylKhayanolide. Adapted from [14]. All structures were drawn with ChemDraw 
7), with $\mathrm{IC}_{50}$ values range of $21.1 \mu \mathrm{M}$ and $39.5 \mu \mathrm{M}$. In another similar study by [53], the cytotoxic activity of two limonoids (ivorenoids $\mathrm{C}$ and $\mathrm{F}$ ) isolated from the ethanolic extract of the stem of $K$. ivorensis against human leukaemia (HL-60) and murine leukaemia (P388) was reported to have shown moderate cytotoxicity against the cancer cells with $\mathrm{IC}_{50}$ values of $0.19 \mu \mathrm{M}$ for HL-60 and $0.63 \mu \mathrm{M}$ for P388.

\section{Antimalarial activity}

Malaria, caused by a protozoan parasite of the genus Plasmodium, is a major public health problem globally, especially in tropical and sub-tropical countries where high morbidity and mortality are recorded [54]. According to the WHO report in 2016, over 216 million malaria cases were reported across 91 countries globally, and over 445,000 deaths resulting from malaria infection were recorded yearly [55]. It is estimated that $90 \%$ of the malaria cases and mortalities occur in sub-Saharan Africa [54]. Children below the age of five are highly susceptible to malaria as death resulting from malaria occurs every $2 \mathrm{~min}$ in children [55]. The global burden of malaria has lingered owing to increased drug-resistant parasite strains in several parts of the world where the Plasmodium is prevalent. Malaria cases keep rising in the remote and rural areas of sub-Saharan Africa, where cheap drugs and medical centres are not available. As a result, most people rely on herbal medicine for the treatment of malaria [56]. In that regard, several limonoids in different parts of Khaya species have been effective against different Plasmodium strains.

Bickii et al. [17] evaluated the in vitro antimalarial activity of limonoids purified from the crude extracts of seeds and bark of $K$. grandifoliola against a chloroquineresistant strain (W2/Indochina) of Plasmodium falciparum. The results showed that five limonoids (methylangolensate, gedunin, 1-deacetylkhivorin, 7deacetylkhivorin and 6-acetyl-swietenolide) were active against the chloroquine-resistant strain of $P$. falciparum with $\mathrm{IC}_{50}$ values range of $1 \mu \mathrm{g} / \mathrm{ml}$ and10 $\mu \mathrm{g} / \mathrm{ml}$. The authors further reported that the antimalarial activities of the purified limonoids were comparable to the results of other limonoids obtained from other plants such as $\mathrm{Aza}$ diratcha indica, Cedrela odorata and Guarea multiflora in the Meliaceae family used in treating malaria.

In another study by [18], the antimalarial efficacy of two limonoids (anthotechol and gedunin) from "whole plant" of $K$. anthotheca was assessed against the W2strain of P. falciparum using $\left[{ }^{3} \mathrm{H}\right]$-hypoxanthine and 48 $h$ culture assay in vitro. The results revealed that anthothechol demonstrated potent antimalarial activity in the two assays with $\mathrm{IC}_{50}$ values of $1.4 \mu \mathrm{M}$ and 0.17 $\mu \mathrm{M}$. Similarly, gedunin was also reported to be effective against the Plasmodium strain in the two assays with $\mathrm{IC}_{50}$ values of 3.1 and $0.14 \mu \mathrm{M}$.

\section{Hepatoprotective activity}

In humans, the liver is considered a major detoxification site and therefore, it is a principal drug exposure target in the body [57]. Liver injuries induced by drugs and liver cirrhosis have been reported to be the ninth main cause of mortality in western and developing countries [38]. Efficient and less-harmful treatments of liver injury, especially with the use of natural compounds, are of interest in the pharmaceuticals [49].

The hepatoprotective activity and molecular mechanisms of action of limonoids from the stem bark of $K$. grandifoliola were evaluated against acetaminophen (APAP)-induced hepatotoxicity in normal human liver L-02 cells line [49]. The results of the study showed that three isolated limonoids, namely 17 -epi-methyl-6hydroxylangolensate, deacetoxy7R-hydroxygedunin and 7deacetoxy-7-oxogedunin demonstrated protective activity against APAP-induced hepatotoxicity as the limonoids improved the cellular antioxidant defense system as well as modified the major processes involved in APAP cell-death mechanism. The increased expression of mitogen-activated protein kinase phosphatase (Mkp)1 and the nuclear translocation of nuclear factor erythroid 2-related factor-2 ( $\mathrm{Nrf} 2)$ were identified as the molecular mechanism of action of protection of the isolated limonoids against APAP- induced hepatotoxicity.

\section{Anti-inflammatory activity}

Inflammation is an activated defense response in the body to living tissue injuries caused by a damaged immune system, microbial infections and other physical agents [58]. Although the basic purpose of inflammatory activation is to contain and get rid of the harmful agents, and eliminate defective tissue parts in order to heal the system, organ and tissue affected, the mediators responsible for these processes in the acute inflammation phase may not progress well, thereby resulting to chronic inflammation [5]. Chronic inflammation has been implicated in the development of several diseases such as arthritis, atherosclerosis and obesity-associated diabetes [19]. Several antiinflammatory and non-steroidal drugs are available in treating inflammation and pain; however, there are several side effects reported with the use of nonsteroidal anti-inflammatory medication. Medicinal plants having anti-inflammatory therapeutic activities with little or no side effects are recommended as a healthy alternative therapy to be exploited in the treatment of inflammation [5].

The anti-inflammatory activity of Khayandirobilde, a limonoid isolated from the stem bark of K. senegalensis, 
was evaluated against lipopolysaccharide (LPS)-stimulated inflammation in mouse macrophages RAW 264.7 and BV-2 microglial cells [19]. Khayandirobilde suppressed several pro-inflammatory mediators in RAW 264.7 and BV-2 microglial cells. Khayandirobilde reduced the production of LPS- induced nitric oxide (NO) in RAW 264.7 and BV-2 with $\mathrm{IC}_{50}$ values of $5.04 \pm 0.14$ $\mu \mathrm{M}$ and $4.97 \pm 0.5 \mu \mathrm{M}$, respectively. Additionally, at both protein and mRNA levels, Khayandirobilde decreased LPS-induced interleukin-6 (IL-6) and tumour necrosis factor- $\alpha$ (TNF- $\alpha$ ), which are pro-inflammatory mediators [19]. These results suggest that this limonoid is capable of exerting anti-inflammatory activity by preventing inflammatory mediators' expression.

Khayasenelide G, another limonoid isolated from the stem bark of $K$. senegalensis, evaluated for its antiinflammatory activity against LPS-induced inflammation in mouse macrophage cell line (RAW 264.7) showed significant anti-inflammatory activity by inhibiting $\mathrm{NO}$ activities in the cell line at an $\mathrm{IC}_{50}$ value of $3.51 \mu \mathrm{M}$ [16].

\section{Neuroprotective activity}

In the human brain, glutamate is involved in a number of physiological activities, including memory, learning, neuronal plasticity and central excitatory neurotransmission [59]. However, when glutamate is excessive, it can stimulate $N$-methyl-D-aspartate receptor resulting in a high inflow of $\mathrm{Ca}^{2+}$, reactive oxygen species, impairment of mitochondrial activity, neurotoxicity and subsequent neuronal cell death $[58,59]$. Moreover, damage to neuronal cells caused by excess glutamate has been implicated in neuropathological and neuropsychiatric maladies such as brain injury, stroke and several other neurodegenerative ailments, and neuroprotection against glutamate-induced neurotoxicity has been a healing approach in treating neurodegenerative disease [60].

In vitro neuroprotective activity of khasenegasin $G$ and seneganolide A isolated from the seeds of $K$. senegalensis was evaluated against "glutamate-induced injury in primary rat cerebellar granule neuronal cells (CGCs)" using MTT assay [61]. The study reported that the two limonoids demonstrated significant neuroprotective activities at a concentration of $10 \mu \mathrm{M}(88.5 \pm 6.4 \%$ and $78.4 \pm$ $5.7 \%$ cell viabilities, respectively) and $1 \mu \mathrm{M}(87.6 \pm 1.2 \%$ and $76.5 \pm 2.0 \%$ cell viabilities, respectively). The neuroprotective activity demonstrated by the two limonoids was comparable to the positive control, edarovone, which showed a cell viability of $86.7 \pm 5.6 \%$ at $50 \mu \mathrm{M}$.

Similarly, Khasenegasin Z, a new andirobin-type limonoid extracted from the seeds of $K$. senegalensis, showed neuroprotective activity when evaluated against glutamate stimulated damage in rat cerebellar granule neuronal cells with increased viability of $83.3 \pm 6.0 \%$ at $10 \mu \mathrm{M}$ and $80.3 \pm 3.2 \%$ at $1 \mu \mathrm{M}[62]$.

\section{Antimicrobial activity}

Globally, infectious diseases are among the leading cause of mortality and account for half of the deaths in tropical regions [63]. The increasing antibiotic resistance resulting from antibiotics' overuse is a common health challenge, particularly for human infectious diseases [64]. This has necessitated the search for healthier and efficient natural product alternatives in treating several microorganisms with little or no toxicity to humans [63]. Antimicrobials that are plant-based represent a wide range of underexploited alternatives that can be used to treat infectious diseases with no such side effects associated with synthetic antimicrobials [63].

Abdelgaleil et al. [65] investigated the in vitro antimicrobial efficiency of a limonoid (3-dideacetylkhivorin) isolated from the stem bark of $K$. ivorensis against three bacterial strains, viz. Bacillus subtilis (Ehrenberg) Cohn (IFO 3009), Micrococcus luteus (Schroeter) Cohn (IFO 12708) and Salmonella enteritidis (Gaertner) Castellani and Chalmers (IFO 3313). The result of the study revealed that 3-dideacetylkhivorin totally prevented the growth of S. enteritidis and B. subtilis at 1 and $2 \mathrm{mg} / \mathrm{ml}$, and $2 \mathrm{mg} / \mathrm{ml}$, respectively.

In another study by [66], four limonoids (3-deacetylkhivorin, 1-deacetylkhivorin, swietmanin B and 3ßacetoxy-1 oxo-methylmeliacate) isolated from the methanol extract of K. senegalensis were evaluated for their antimicrobial efficacy against Staphylococcus aureus (ATCC25923), Pseudomonas aeruginosa (ATCC27853) and two clinically isolated bacterial strains MRSA 92 and MRSA 98 using the 2-fold dilution method. The authors reported that the four limonoids (at a MIC value of $12.5 \mu \mathrm{g} / \mathrm{ml}$ ) showed antimicrobial activities against MRSA 92, MRSA 98 and $P$. aeruginosa.

In the studies carried out by [39], in vitro antitrypanosomal and antileishmanial activities of two limonoids (Grandifolione and 7-deacetylkhivorin) isolated from the petroleum ether seed extract of $K$. anthotheca were evaluated against Trypanosoma brucei brucei, Trypanosoma brucei rhodesiense, Trypanosoma cruzi and Leishmania donovani. Both Grandifolione and 7-deacetylkhivorin showed activity against Trypanosoma brucei rhodesiense (with $\mathrm{IC}_{50}$ values of $10.66,16.88 \mu \mathrm{g} / \mathrm{ml}$, respectively), Trypanosoma cruzi (with $\mathrm{IC}_{50}$ values of $20.97,31.82 \mu \mathrm{g} /$ $\mathrm{ml}$, respectively) and Leishmania donovani (with $\mathrm{IC}_{50}$ values of $13.31,36.71 \mu \mathrm{g} / \mathrm{ml}$, respectively). The results justify the traditional use of $K$. anthotheca in treating microbial infections.

\section{Antifungal activity}

The major focus of integrated pest management is to effectively manage and control pests without causing harm to humans, animals and the environment. In recent 
times, bioactive natural compounds, particularly secondary metabolites with antifungal activities that are nontoxic to humans, highly biodegradable and with very low persistence in the environment are considered alternatives to conventional pesticides in pest management and control [65].

Several plants with fungitoxic activities against pathogens have been reported in the literature. Using radial growth approach, [65] investigated in vitro antifungal activity of isolated limonoids from the diethyl ether of the stem bark of $K$. ivorensis against a plant pathogen fungus (Botrytis cinerea Pers.). The results revealed that the 10 limonoids (methyl angolensate, methyl 6-hydroxyangolensate, 3-deacetylkhivorin, 3,7-dideacetylkhivorin, 1,3,7-trideacetylkhivorin, 7deacetylgedunin, 7-deacetoxy-7-oxogedunin, swietenine, 3-O-detigloyl 3-O-acetylswietenine and 3-O-acetylswietenolide) isolated from the stem bark of $K$. ivorensis exhibited antifungal activities at the test concentrations. It was reported that the highest fungal growth inhibition was demonstrated in methyl angolensate $(62.8 \%$ at $1000 \mathrm{mg} / \mathrm{L}$ and $73.3 \%$ at $1500 \mathrm{mg} /$ L) and 1,3,7-trideacetylkhivorin $(64 \%$ at $1000 \mathrm{mg} / \mathrm{L}$ and $68.6 \%$ at $1500 \mathrm{mg} / \mathrm{L}$ ).

\section{Antifeedant activity}

Some secondary metabolites found in plants have been reported to have vital adaptive implication in protection against herbivory, thus, serving as defense chemicals and protecting the plant against wounds caused by insect feeding [67]. These naturally occurring antifeedants in plants have been recognized as potential alternatives to traditional insecticides in pest management. Furthermore, the feeding inhibition conferred by these secondary metabolites in plants has been considered advantageous relative to conventional chemicals as they target the herbaceous host insect without damaging non-target insects or organisms and act with little or low environmental impact [68].

Limonoids in plant species including $K$. senegalensis $[20,68,69]$ have been reported to show marked antifeedant activities against some insects. In the study of [21], the antifeedant effects of 15 limonoids (Khayanone, Khayalactol, Seneganolide, 2-hydroxyseneganolide, Khayanolide A, 1-O-acetylKhayanolide A, Khayanolide C, Khayanolide B, 1-O-acetylKhayanoilde B, 6dehydroxyKhayanolide B, Khayanolide D, Khayanoside, Methyl angolensate, Methyl 6-hydroxyangolensate and Methyl 6-acetoxyangolensate) isolated from ether and acetone extracts of the stem bark of $K$. senegalensis were evaluated against third-instar larvae of cotton leafworm Spodoptera littoralis (Boisd.) using the conventional choice leaf disc method. The isolated limonoids demonstrated antifeedant actions at concentrations ranging between 100 and $1000 \mu \mathrm{g} / \mathrm{ml}$. The highest antifeedant activity was demonstrated in Khayalactol with an antifeeding percentage of $83.8 \%$ at $1000 \mu \mathrm{g} / \mathrm{ml}$ while at the same concentration, Khayanoside showed the least antifeeding percentage of $15.1 \%$ (Table 2).

A great diversity of secondary metabolites like limonoids are produced in a narrowed taxonomic group in the kingdom Plantae, and many of them hold vital biological activities and pharmaceutical potentials [13]. Based on the available data published between 2000 and 2020, this review has summarized the several documented limonoids bioactivities, including anticancer, antimalarial, hepatoprotection, anti-inflammatory, neuroprotection, antimicrobial, antifungal and antifeedant in the genus Khaya. The study revealed $K$. senegalensis as the most well-researched species with the most prominent biological activities and traditional uses in the genus. Pharmacological investigations carried out on limonoids isolated from different plant part in the genus provided empirical support for some of its ethnomedicinal uses, mainly in treating malaria, fever, liver problem, microbial infections, and nervous disorder. Most of the investigated biological activities of limonoids in the genus are in vitro-based assays. However, only a few studies on anticancer, anti-inflammatory, hepatoprotective and neuroprotection activities have employed in vivo-based models.

The limonoids isolated from different parts in Khaya species showed potent cytotoxic effects in different cancer cell lines based on in vitro and in vivo studies and can be employed as a complementary agent in cancer treatment and management.

With the alarming spread of multi-drug and chloroquine-resistant strains of Plasmodium, the integration of limonoids from Khaya species as combination treatments in malaria control programmes could be exploited as they have demonstrated to be potent sources of cheap and effective antimalarial agents as revealed in this study.

Several phytochemicals in plants such as phyllanthin, silymarin, neoandrographolide, $\beta$-sitosterol and betalain, among others, have been reported to demonstrate potent hepatoprotective properties [88]. The pharmacological investigation of the hepatoprotective activity of limonoids provided empirical support for the ethnomedicinal use of Khaya in treating liver problems. In various central nervous system disorders such as epilepsy, Alzheimer's disease and ischemia, glutamate-induced oxidative damage is a key driver to neuronal degeneration and death [59]. In vitro studies on evaluation of neuroprotective activity revealed that limonoids in the genus Khaya showed potent neuroprotective effects in glutamateinduced injury in primary rat cerebellar granule neuronal cells. Further clinical studies need to be done to 
Table 2 Other (non-limonoid) reported bioactivities in the genus Khaya for the period 2000-2020

\begin{tabular}{|c|c|c|c|c|c|}
\hline $\begin{array}{l}\text { Khaya } \\
\text { species }\end{array}$ & Activity & Part & Solvent & Phytochemicals detected & References \\
\hline $\begin{array}{l}\text { K. } \\
\text { senegalensis }\end{array}$ & $\begin{array}{l}\text { Anti-diabetic at } 300 \mathrm{mg} / \mathrm{kg} \text { BW on T2D } \\
\text { induced male Sprague-Dawley rats }\end{array}$ & Root & Ethanol & N.r. & [69] \\
\hline $\begin{array}{l}\text { K. } \\
\text { senegalensis }\end{array}$ & $\begin{array}{l}\text { Immunostimulating activity against } \\
\text { amastigotes }(E C 50=3.85 \text { and } 3.98 \mathrm{mg} / \mathrm{ml} \text { for } \\
\text { catechin- }(4 a, 6)-\text { catechin and catechin- }(4 a, 8) \text { - } \\
\text { catechin, respectively) }\end{array}$ & Bark & Methanol & $\begin{array}{l}\text { Catechin-(4a,6)-catechin and catechin-(4a, } \\
\text { 8)-catechin) }\end{array}$ & {$[70]$} \\
\hline $\begin{array}{l}\text { K. } \\
\text { senegalensis }\end{array}$ & $\begin{array}{l}\text { Anthelmintic against gastrointestinal } \\
\text { nematodes of sheep. } L C_{50} 0.69 \mathrm{mg} / \mathrm{ml} \\
\text { (aqueous), } L C_{50} 0.51 \mathrm{mg} / \mathrm{ml} \text { (ethanolic). }\end{array}$ & Bark & $\begin{array}{l}\text { Ethanol, } \\
\text { Aqueous }\end{array}$ & N.r. & [71] \\
\hline $\begin{array}{l}\text { K. } \\
\text { senegalensis }\end{array}$ & $\begin{array}{l}\text { Anticoccidial at } 400 \mathrm{mg} / \mathrm{kg} \text { and } 800 \mathrm{mg} / \mathrm{kg} \\
\text { against experimentally induced coccidiosis in } \\
\text { broiler chicken }\end{array}$ & Stem bark & Aqueous & $\begin{array}{l}\text { Tannins, saponin, cardiac glycosides and } \\
\text { steroids }\end{array}$ & [72] \\
\hline $\begin{array}{l}\text { K. } \\
\text { senegalensis }\end{array}$ & $\begin{array}{l}\text { Antidiarrheal in castor oil-induced diarrhoea in } \\
\text { albino rats }\end{array}$ & Stem bark & $\begin{array}{l}\text { Ethanol, } \\
\text { Aqueous }\end{array}$ & $\begin{array}{l}\text { Flavonoids, tannins and cardiac } \\
\text { glycosides }\end{array}$ & [73] \\
\hline $\begin{array}{l}\text { K. } \\
\text { senegalensis }\end{array}$ & $\begin{array}{l}\text { Anti-ulcer at 200, 400, } 800 \mathrm{mg} / \mathrm{kg} \text { against } \\
\text { ethanol-induced gastric ulceration in Wistar } \\
\text { rats }\end{array}$ & Stem bark & Methanol & $\begin{array}{l}\text { Alkaloids, carbohydrate, glycosides, } \\
\text { flavonoids, steroids, tannins and } \\
\text { triterpenes }\end{array}$ & [74] \\
\hline $\begin{array}{l}\text { K. } \\
\text { senegalensis }\end{array}$ & $\begin{array}{l}\text { Nematocidal at } 60 \mathrm{mg} \text { on root-knot nema- } \\
\text { todes in cowpea }\end{array}$ & Bark & NA & N.r. & [75] \\
\hline $\begin{array}{l}\text { K. } \\
\text { senegalensis }\end{array}$ & $\begin{array}{l}\text { Anti-Trypanosoma against } T \text {. brucei brucei in } \\
\text { infected Wistar rats }\end{array}$ & Stem bark & Methanol & N.r. & {$[76]$} \\
\hline $\begin{array}{l}\text { K. } \\
\text { senegalensis }\end{array}$ & $\begin{array}{l}\text { Antidermatophytic (MIC } 1.2-2.4 \mu \mathrm{g} / \mathrm{ml} \text { ) against } \\
\text { Trichophyton mentagrophyte, Trichophyton } \\
\text { verrucosum, Trichophyton terrestre and } \\
\text { Microsporum canis }\end{array}$ & Stem bark & $\begin{array}{l}\text { Methanol, } \\
\text { Aqueous, } \\
\text { Chloroform }\end{array}$ & $\begin{array}{l}\text { Alkaloids, glycosides, tannins, flavonoids, } \\
\text { saponins, steroids and anthraquinone }\end{array}$ & [77] \\
\hline $\begin{array}{l}\text { K. } \\
\text { senegalensis }\end{array}$ & $\begin{array}{l}\text { Antioxidant with } I_{50} 3.37 \pm 0.61-9.900 \pm 1.2 \\
\mathrm{mg} / \mathrm{ml} \text { for } \mathrm{DPPH}\end{array}$ & Leaves & $\begin{array}{l}\text { Aqueous, } \\
\text { ethanol, } \\
\text { methanol } \\
\text { and Butanol }\end{array}$ & Flavonoids and phenols & [78] \\
\hline $\begin{array}{l}\text { K. } \\
\text { senegalensis }\end{array}$ & $\begin{array}{l}\text { Antioxidant with } I C_{50} 46,37 \text { and } 64 \mu \mathrm{l} \text { for } \\
\text { leaves, root and stem bark, respectively for } \\
\text { xanthine assay; } \mathrm{I}_{50} 178,91 \text { and } 122 \mu \mathrm{l} \text { for } \\
\text { leaves, root and stem bark, respectively for 2- } \\
\text { deoxyguanosine assay }\end{array}$ & $\begin{array}{l}\text { Leaves, root, } \\
\text { stem bark }\end{array}$ & Methanol & $\begin{array}{l}\text { Catechin, rutin, quercetin rhamnoside, } \\
\text { catechin and procyanidins }\end{array}$ & [79] \\
\hline $\begin{array}{l}\text { K. } \\
\text { grandifoliola }\end{array}$ & $\begin{array}{l}\text { Gastric antisecretory at } 50-500 \mathrm{mg} / \mathrm{kg} \text { in } \mathrm{HCl} / \\
\text { ethanol-induced gastric lesions in male Wistar } \\
\text { rats }\end{array}$ & Stem bark & Aqueous & $\begin{array}{l}\text { Tannins, alkaloids, saponins, flavonoids, } \\
\text { anthocyanins, phenols, quinones, } \\
\text { coumarins, sterols, triterpenoids, and } \\
\text { glycosides }\end{array}$ & {$[80]$} \\
\hline $\begin{array}{l}\text { K. } \\
\text { grandifoliola }\end{array}$ & $\begin{array}{l}\text { Desmutagenic and antimutagenic activities in } \\
\text { ethyl methanesulphonate and ribose lysine } \\
\text { induced mutagen in Salmonella typhimurium } \\
\text { TA100 (His). }\end{array}$ & Leaves, flower & Ethanol & $\begin{array}{l}\text { Quercetin 3-O-rhamnoglucoside, } \\
\text { quercetin 3-O-rhamnoside, quercetin 3- } \\
\text { O-glucoside, quercetin and 6- } \\
\text { methoxycoumarin-7-O arabinofuranoside }\end{array}$ & [81] \\
\hline $\begin{array}{l}\text { K. } \\
\text { grandifoliola }\end{array}$ & $\begin{array}{l}\text { In vivo antiviral activity at } 100 \mu \mathrm{g} / \mathrm{ml} \text { in } \\
\text { hepatitis } C \text { virus }\end{array}$ & Bark & $\begin{array}{l}\text { Methylene } \\
\text { chloride/ } \\
\text { methanol } \\
(50: 50 \mathrm{v} / \mathrm{v})\end{array}$ & $\begin{array}{l}\text { Benzene, 1,1'-(oxydiethylidene) bis (1), } \\
\text { carbamic acid, (4-methylphenyl)-, 1- } \\
\text { phenyl (2) and 6-phenyl, 4-(1'- } \\
\text { oxyethylphenyl) }\end{array}$ & [29] \\
\hline $\begin{array}{l}\text { K. } \\
\text { grandifoliola }\end{array}$ & $\begin{array}{l}\text { Insecticidal activity } 85 \% \text { against Rhyzopertha } \\
\text { dominica and } 80 \% \text { against Tribolium castaneum }\end{array}$ & $\begin{array}{l}\text { Essential oil } \\
\text { from stem bark }\end{array}$ & $n$-hexane & $\begin{array}{l}\text { a-pinene, limonene, } \beta \text {-carophyllene, } \beta \text { - } \\
\text { pinene, } a \text {-phellandrene and citronellol }\end{array}$ & [82] \\
\hline $\begin{array}{l}\text { K. } \\
\text { grandifoliola }\end{array}$ & $\begin{array}{l}\text { Molluscicidal activity (100\% at } 1 \mathrm{~g} / \mathrm{L} \text { ) against } \\
\text { freshwater snails. }\end{array}$ & Bark & Ethanol & N.r. & [83] \\
\hline $\begin{array}{l}\text { K. } \\
\text { grandifoliola }\end{array}$ & $\begin{array}{l}\text { Immunomodulatory activity at } 200 \mathrm{\mu g} / \mathrm{ml} \text { on } \\
\text { human peripheral blood mononuclear cells. }\end{array}$ & $\begin{array}{l}\text { Polysaccharide } \\
\text { fractions of } \\
\text { stem bark }\end{array}$ & Ethanol & $\begin{array}{l}\text { Glucose, galactose, arabinose and } \\
\text { rhamnose }\end{array}$ & [84] \\
\hline $\begin{array}{l}\text { K. } \\
\text { anthotheca }\end{array}$ & $\begin{array}{l}\text { Antiplasmodial activity }\left(\mathrm{IC}_{50} 0.955 \mu \mathrm{g} / \mathrm{ml}\right) \\
\text { against Plasmodium falciparum and }\end{array}$ & Seeds & $\begin{array}{l}\text { Petroleum } \\
\text { ether }\end{array}$ & N.r. & [39] \\
\hline
\end{tabular}


Table 2 Other (non-limonoid) reported bioactivities in the genus Khaya for the period 2000-2020 (Continued)

\begin{tabular}{|c|c|c|c|c|c|}
\hline $\begin{array}{l}\text { Khaya } \\
\text { species }\end{array}$ & Activity & Part & Solvent & Phytochemicals detected & References \\
\hline $\begin{array}{l}\text { K. } \\
\text { anthotheca }\end{array}$ & $\begin{array}{l}\text { Antiplatelet activity }\left(\mathrm{EC}_{50} 0.97 \pm 0.03 \mu \mathrm{g} / \mathrm{ml}\right) \text { in } \\
\text { adrenaline (epinephrine) induced platelet } \\
\text { aggregation in equine platelets. }\end{array}$ & Leaves & Acetone & N.r. & [85] \\
\hline $\begin{array}{l}\text { K. } \\
\text { anthotheca }\end{array}$ & $\begin{array}{l}\left.\text { Antioxidant (EC } \mathrm{EC}_{50} 0.10\right) \text { for TEAC assay and } \\
\left(\mathrm{EC}_{50} 176.40 \pm 26.56 \mu \mathrm{g} / \mathrm{ml} \text { ) for DPPH assay. }\right.\end{array}$ & Leaves & Acetone & N.r. & {$[85]$} \\
\hline K. ivorensis & $\begin{array}{l}\text { Antioxidant }\left(\mathrm{I} \mathrm{C}_{50} 2.08-4.48 \mu \mathrm{g} / \mathrm{ml}\right) \text { for DPPH } \\
\text { and }\left(\mathrm{I} \mathrm{C}_{50} 2.78 \mu \mathrm{g} / \mathrm{ml}\right) \text { for ABTS assay. }\end{array}$ & $\begin{array}{l}\text { Stem bark, } \\
\text { root }\end{array}$ & Ethanolic & $\begin{array}{l}\text { Alkaloids, flavonoids, tannins, saponins, } \\
\text { steroids and triterpenoids. }\end{array}$ & {$[86]$} \\
\hline K. ivorensis & $\begin{array}{l}\text { Termicidal activity ( } 100 \% \text { mortality at } 200 \text { and } \\
400 \mathrm{mg} / \mathrm{ml} \text { ) against subterranean termites. }\end{array}$ & Stem bark & $\begin{array}{l}\text { Ethanolic, } \\
\text { aqueous }\end{array}$ & N.r. & [87] \\
\hline
\end{tabular}

N.r. not reported

elucidate the mechanism via which the neuroprotective effect of limonoid is mediated, after which limonoids can then be explored as potential agents in the treatment of neurological disorders. The antimicrobial and antifungal activities of limonoids against several important pathogens support the traditional use of Khaya species in treating several microbial infections, including sexually transmitted infections and diarrhoea.

\section{Conclusion}

Though limited in their occurrence in the plant kingdom, limonoids are abundant in the Khaya species. The study revealed Khaya senegalensis as the most wellresearched species with the most documented biological activities and traditional uses in the genus. In addition to the several uses of Khaya species in traditional medicine, the biological activities of limonoids, as outlined in this study, display great potentials for drug discovery.

While investigations on the biological activities of limonoids in the genus Khaya have focused mostly on the stem bark of $K$. senegalensis, other tree parts and species in the genus may also contribute as alternative sources of bioactive compounds. Therefore, there is a need for more investigations on other tree parts and species to discover and develop more biologically active compounds that may be of significant pharmaceutical implications. Additionally, clinical investigations using in vivo approaches should be carried out on the reported bioactivities of limonoids in the genus Khaya to validate their use as potential treatments for different human ailments.

\footnotetext{
Abbreviations

ABTS: 2,2'-Azino-bis(3-ethylbenzothiazoline-6-sulfonic acid); AnthoNPs: Anthothecol encased poly (D,L-lactic-co-glycolic acid) nanoparticles; BW: Body weight; DNA: Deoxyribonucleic acid; DPPH: 2,2-Diphenyl-1picrylhydrazyl; $\mathrm{EC}_{50}$ : Half maximal effective concentration; $I \mathrm{C}_{50}$ : The half maximal inhibitory concentration; $L_{50}$ : Lethal concentration required to kill 50\% of the population; LPS: Lipopolysaccharide; MIC: Minimum inhibitory concentration; Mkp-1: Mitogen-activated protein kinase phosphatase; mRNA: Messenger ribonucleic acid; MTT: 3-(4,5-Dimethylthiazol-2-yl)-2,5diphenyltetrazolium bromide; NO: Nitric oxide; Nrf2: Nuclear factor erythroid 2-related factor-2; T2D: Type 2 diabetes; TEAC: Trolox equivalent antioxidant capacity; WHO: World Health Organization
}

\section{Acknowledgements}

Not applicable.

\section{Authors' contributions}

TLO and CAO conceptualized, designed and wrote the manuscript. AEA has substantively revised the manuscript and was a major contributor in writing the manuscript. All authors have read and agreed to the published version of the manuscript.

\section{Funding}

This research received no external funding.

\section{Availability of data and materials}

All data generated or analyzed during this study are included in this published article.

Ethics approval and consent to participate

Not applicable.

\section{Consent for publication}

Not applicable.

\section{Competing interests}

The authors declare no competing interest.

\section{Author details}

${ }^{1}$ University of Fort Hare, Alice 5700, South Africa. ${ }^{2}$ Forestry Research Institute of Nigeria, P.M.B 5054, Jericho Hills, Ibadan, Nigeria. ${ }^{3}$ School of Life Sciences, University of KwaZulu-Natal, Durban 4001, South Africa.

Received: 28 September 2020 Accepted: 3 February 2021

Published online: 24 March 2021

\section{References}

1. Anand U, Jacobo-Herrera N, Altemimi A, Lakhssassi N (2019) A comprehensive review on medicinal plants as antimicrobial therapeutics: potential avenues of biocompatible drug discovery. Metabolites 9:1-13. https://doi.org/10.3390/metabo9110258

2. Braga TM, Rocha L, Chung TY, Oliveira RF, Pinho C, Oliveira Al, Morgado J، Cruz A (2020) Biological activities of gedunin-a limonoid from the Meliaceae family. Molecules 25:9-11. https://doi.org/10.3390/molecules2503 0493

3. Shakya AK (2016) Medicinal plants: Future source of new drugs. Int J Herb Med 4:59-64. https://doi.org/10.13140/RG.2.1.1395.6085

4. Patra JK, Das G, Lee S, Kang SS, Shin HS (2018) Selected commercial plants: a review of extraction and isolation of bioactive compounds and their pharmacological market value. Trends Food Sci Technol 82:89-109. https:// doi.org/10.1016/j.tifs.2018.10.001

5. Oguntibeju $O O$ (2018) Medicinal plants with anti-inflammatory activities from selected countries and regions of Africa. J Inflamm Res 1:307-317

6. Olatunji TL, Afolayan AJ (2018) The suitability of chili pepper (Capsicum annuum L.) for alleviating human micronutrient dietary deficiencies: a review. Food Sci Nutr 6:2239-2251. https://doi.org/10.1002/fsn3.790 
7. Idris OA, Wintola OA, Afolayan AJ (2019) Evaluation of the bioactivities of Rumex crispus L. leaves and root extracts using toxicity, antimicrobial, and antiparasitic assays. Evidence-Based Complement Altern Med 2019:1-13. https://doi.org/10.1155/2019/6825297

8. Rout SP, Choudary KA, Kar DM, Das L, Jain A (2009) Plants in traditional medicinal system-future source of new drugs. Int J Pharm Pharm Sci $1: 1-23$

9. Tundis R, Loizzo MR, Menichini F (2014) An overview on chemical aspects and potential health benefits of limonoids and their derivatives. Crit Rev Food Sci Nutr 54:225-250. https://doi.org/10.1080/10408398.2011.581400

10. Sun YP, Jin WF, Wang YY, Wang G, Morris-Natschke SL, Liu JS, Wang GK, Lee $\mathrm{KH}$ (2018) Chemical structures and biological activities of limonoids from the genus Swietenia (meliaceae). Molecules 23:1-17. https://doi.org/10.33 90/molecules23071588

11. Fang X, Di Y, Hao X (2011) The advances in the limonoid chemistry of the Meliaceae family. Curr Org Chem 15:1363-1391

12. Akihisa T, Nishimoto Y, Ogihara E, Matsumoto M, Zhang J, Abe M (2017) Nitric oxide production-inhibitory activity of limonoids from Azadirachta indica and Melia azedarach. Chem Biodivers 14:1-10. https://doi.org/10.1 002/cbdv.201600468

13. Ibrahim MA, Koorbanally NA, Islam MS (2014) Antioxidative activity and inhibition of key enzymes linked to type-2 diabetes (a-Glucosidase and aAmylase) by Khaya senegalensis. Acta Pharm 64:311-324. https://doi.org/1 0.2478/acph-2014-0025

14. Zhang H, Wang X, Chen F, Androulakis XM, Wargovich MJ (2007) Anticancer activity of limonoid from Khaya senegalensis. Phyther Res 21:731-734. https://doi.org/10.1002/ptr.2148

15. Verma RK, Yu W, Singh SP, Shankar S, Srivastava RK (2015) Anthothecolencapsulated PLGA nanoparticles inhibit pancreatic cancer stem cell growth by modulating sonic hedgehog pathway. Nanomed Nanotechnol Biol Med 11:2061-2070. https://doi.org/10.1016/j.nano.2015.07.001

16. Zhang WY, Qiu L, Lu QP, Zhou MM, Luo J, Li Y (2018) Furan fragment isomerized mexicanolide-type limonoids from the stem barks of Khaya senegalensis. Phytochem Lett 24:110-113. https://doi.org/10.1016/j.phytol.2 018.01 .020

17. Bickii J, Njifutie N, Ayafor Foyere J, Basco LK, Ringwald P (2000) In vitro antimalarial activity of limonoids from Khaya grandifoliola C.D.C. (Meliaceae). J Ethnopharmacol 69:27-33. https://doi.org/10.1016/S0378-8741(99)00117-8

18. Lee SE, Kim MR, Kim JH, Takeoka GR, Kim TW, Park BS (2008) Antimalarial activity of anthothecol derived from Khaya anthotheca (Meliaceae). Phytomedicine 15:533-535. https://doi.org/10.1016/j.phymed.2007.08.001

19. Zhou MM, Zhang WY, Li RJ, Guo C, Wei SS, Tian XM, Luo J, Kong LY (2018) Anti-inflammatory activity of Khayandirobilide A from Khaya senegalensis via NF-kB, AP-1 and p38 MAPK/Nrf2/HO-1 signaling pathways in lipopolysaccharide-stimulated RAW 264.7 and BV-2 cells. Phytomedicine 42: 152-163. https://doi.org/10.1016/j.phymed.2018.03.016

20. Nakatani M, Abdelgaleil SAM, Kurawaki J, Okamura H, Iwagawa T, Doe M (2001) Antifeedant rings B and D opened limonoids from Khaya senegalensis. J Nat Prod 64:1261-1265. https://doi.org/10.1021/np010082k

21. Abdelgaleil SAM, Nakatani M (2003) Antifeeding activity of limonoids from Khaya senegalensis (Meliaceae). J Appl Entomol 127:236-239. https://doi. org/10.1046/j.1439-0418.2003.00742.x

22. Hung CD, Trueman SJ (2011) In vitro propagation of the African Mahogany Khaya senegalensis. New For 42:117-130. https://doi.org/10.1007/s11056-01 0-9241-9

23. Alam K, Rani S, Syedul A (2012) Khaya anthotheca (Welw.) C.DC. (Meliaceae)an exotic species in Bangladesh. Bangladesh Assoc Plant Taxon 19:95-97

24. The plant list (2013). http://www.theplantlist.org/tpl1.1/search?q=khaya. Accessed 15 Sep 2020

25. Hashem F, El-Souda S, Selim A, Shaker K, Maamoun A, Aboutabl E (2014) Composition of lipoidal matter and evaluation of hepatoprotective, cytotoxic, and antioxidant activities of Khayd grandifoliola C.DC. growing in Egypt. Egypt Pharm J 13:13. https://doi. org/10.4103/1687-4315.135576

26. Filho JB, di Carvalho MA, de Oliveira LS, Konzen ER, Campos WF, Brondani GE (2016) Propagação de Khaya anthotheca: Enxertia interespecífica com swietenia macrophylla e mergulhia aérea. Cerne 22:475-484. https://doi. org/10.1590/01047760201622042232

27. Danquah JA, Appiah M, Ari P (2011) Eco-geographic variation in leaf morphology of African mahogany (Khaya anthotheca and Khaya ivorensis) Provenances in Ghana. Eur J Sci Res 51:18-28
28. Opuni-Frimpong E (2008) Khaya grandifoliola (PROTA). In: Louppe D, OtengAmoako AA, Brink M (eds) PROTA (Plant Resources of Tropical Africa / Ressources végétales de l'Afrique tropicale). PROTA (Plant Resources of Tropical Africa / Ressources végétales de l'Afrique tropicale), Wageningen, Netherlands

29. Galani BRT, Sahuc ME, Sass G, Njayou FN, Loscher C, Mkounga P, Deloison G, Brodin P, Rouillé Y, Tiegs G, Séron K, Moundipa PF (2016) Khaya grandifoliola C.DC: A potential source of active ingredients against hepatitis C virus in vitro. Arch Virol 161:1169-1181. https://doi.org/10.1007/s00705-01 6-2771-5

30. Lemmens RH (2008) Khaya ivorensis (PROTA). In: Louppe D, Oteng-Amoako AA, Brink M (eds) PROTA (Plant Resources of Tropical Africa / Ressources végétales de I'Afrique tropicale), Wageningen, Netherlands

31. Ky-Dembele C, Tigabu M, Bayala J, Odén PC (2014) Inter- and intraprovenances variations in seed size and seedling characteristics of Khaya senegalensis A. Juss in Burkina Faso. Agr Syst 88:311-320. https://doi.org/10.1 007/s10457-014-9684-7

32. Nikiema A, Pasternak D (2008) Khaya senegalensis (Desr.) A.Juss. PROTA (Plant Resources of Tropical Africa / Ressources végétales de l'Afrique tropicale), Wageningen, Netherlands

33. Adeniji K, Ariwaodo J, Osiyemi O, Ugbogu O (2018) A survey of stem bark used in traditional health care practices in some popular herbal markets in Osun state, Nigeria. J Med Plants Stud 6:08-12

34. Titanji PV, Zofou D, Ngemanya MM (2008) The antimalarial potential of medicinal plants used for the treatment of malaria in Cameroonian folk medicine. Afr J Tradtional Complement Altern Med 5:302-321

35. Tchacondo T, Karou SD, Agban A, Bako M, Batawila K, Bawa ML, Gbeassor M, De Souza C (2012) Medicinal plants use in central Togo (Africa) with an emphasis on the timing. Pharm Res 4:92-103. https://doi.org/10.4103/09748490.94724

36. Idu M, Erhabor JO, Efijuemue HM (2010) Documentation on medicinal plants sold in markets in Abeokuta, Nigeria. Trop J Pharm Res 9:110-118. https://doi.org/10.4314/tjpr.v9i2.53696

37. Amoateng P, Quansah E, Karikari TK, Asase A, Osei-Safo D, Kukuia KKE, Amponsah IK, Nyarko AK (2018) Medicinal plants used in the treatment of mental and neurological disorders in Ghana. Evidence-based Complement Altern Med 2018:1-14. https://doi.org/10.1155/2018/8590381

38. Njayou FN, Kouam AF, Simo BFN, Tchana AN, Moundipa PF (2016) Active chemical fractions of stem bark extract of Khaya grandifoliola C.DC and Entada africana Guill. et Perr. synergistically protect primary rat hepatocytes against paracetamol-induced damage. BMC Complement Altern Med 16:111. https://doi.org/10.1186/s12906-016-1169-y

39. Obbo CJD, Makanga B, Mulholland DA, Coombes PH, Brun R (2013) Antiprotozoal activity of Khaya anthotheca, (Welv.) C.D.C. a plant used by chimpanzees for self-medication. J Ethnopharmacol 147:220-223. https:// doi.org/10.1016/j.jep.2013.03.007

40. Obbo CJD, Kariuki ST, Gathirwa JW, Olaho-Mukani W, Cheplogoi PK, Mwangi EM (2019) In vitro antiplasmodial, antitrypanosomal and antileishmanial activities of selected medicinal plants from Ugandan flora: Refocusing into multi-component potentials. J Ethnopharmacol 229:127-136. https://doi. org/10.1016/j.jep.2018.09.029

41. Koné WM, Kamanzi Atindehou K, Terreaux C, Hostettmann K, Traoré D, Dosso M (2004) Traditional medicine in North Côte-d'lvoire: Screening of 50 medicinal plants for antibacterial activity. J Ethnopharmacol 93:43-49. https://doi.org/10.1016/j.jep.2004.03.006

42. Inngjerdingen K, Nergård CS, Diallo D, Mounkoro PP, Paulsen BS (2004) An ethnopharmacological survey of plants used for wound healing in Dogonland, Mali, West Africa. J Ethnopharmacol 92:233-244. https://doi. org/10.1016/j.jep.2004.02.021

43. Magassouba FB, Diallo A, Kouyaté M, Mara F, Mara O, Bangoura O, Camara A, Traoré S, Diallo AK, Zaoro M, Lamah K, Diallo S, Camara G, Traoré S, Kéita A, Camara MK, Barry R, Kéita S, Oularé K, Barry MS, Donzo M, Camara K, Toté K, Vanden BD, Totté J, Pieters L, Vlietinck AJ, Baldé AM (2007) Ethnobotanical survey and antibacterial activity of some plants used in Guinean traditional medicine. J Ethnopharmacol 114:44-53. https://doi.org/1 0.1016/j.jep.2007.07.009

44. Ajayi TO, Moody JO, Anthony CS (2019) Ethnobotanical survey of plants used in the management of hypertension in Ibadan North Local Government Area of Oyo State, Nigeria. Nig J Pharm Res 15:61-73

45. Zhang Y, Xu H (2017) Recent progress in the chemistry and biology of limonoids. RSC Adv 7:35191-35220. https://doi.org/10.1039/c7ra04715k 
46. Narender T, Khaliq T, Shweta RKP, Sharma RK (2007) Occurrence, biosynthesis, biological activity and NMR spectroscopy of D and B, D Ring Seco-limonoids of Meliaceae Family. Nat Prod Commun 2:203-221. https:// doi.org/10.1177/1934578X0700200219

47. Ji KL, Liao SG, Zheng XL, Na Z, Bin HH, Zhang P, Xu YK (2014) Limonoids from the fruits of Khaya ivorensis. Molecules 19:3004-3011. https://doi.org/1 0.3390/molecules 19033004

48. Tchimene MK, Tane P, Ngamga D, Connolly JD, Farrugia L (2005) Four tetranortriterpenoids from the stem bark of Khaya anthotheca. Phytochemistry 66:1088-1093. https://doi.org/10.1016/j.phytochem.2005.03.028

49. Kouam AF, Yuan F, Njayou FN, He H, Tsayem RF, Oladejo BO, Song F, Moundipa PF, Gao GF (2017) Induction of Mkp-1 and nuclear translocation of Nrf2 by limonoids from Khaya grandifoliola C.DC protect L-02 hepatocytes against acetaminophen-induced hepatotoxicity. Front Pharmacol 8:1-18. https://doi.org/10.3389/fphar.2017.00653

50. Li Y, Lu Q, Luo J, Wang J, Wang X, Zhu M, Kong L (2015) Limonoids from the stem bark of Khaya senegalensis. Chem Pharm Bull 63:305-310. https:// doi.org/10.1248/cpb.c14-00770

51. Majeed S, Aripin FHB, Shoeb NSB, Danish M, Ibrahim MNM, Hashim R (2019) Bioengineered silver nanoparticles capped with bovine serum albumin and its anticancer and apoptotic activity against breast, bone and intestinal colon cancer cell lines. Mater Sci Eng C 102:254-263. https://doi.org/10.101 6/j.msec.2019.04.041

52. He Z, Liu K, Byrne HJ, Cullen PJ, Tian F, Curtin JF (2019) Combination strategies for targeted delivery of nanoparticles for cancer therapy. Elsevier Inc.

53. Wu W, Zhang H, Liu H, Dong S, Wu Y, Ding J, Yue J (2014) Ivorenoids A - F : Limonoids from Khaya ivorensis. Tetrahedron 70:3570-3575. https://doi.org/1 0.1016/j.tet.2014.04.007

54. Badirzadeh A, Naderimagham S, Asadgol Z, Mokhayeri Y, Khosravi A (2016) Burden of malaria disease in Iran, 1990-2010: findings from the global burden of disease study 2010. Arch Iran Med 19:241-247

55. World Health Organization (WHO) (2018) World Malaria Day 2018 "Ready to beat malaria"

56. Tepongning RN, Lucantoni L, Nasuti CC, Dori GU, Yerbanga SR, Lupidi G, Marini C, Rossi G, Esposito F, Habluetzel A (2011) Potential of a Khaya ivorensis-Alstonia boonei extract combination as antimalarial prophylactic remedy. J Ethnopharmacol 137:743-751. https://doi.org/10.1016/j.jep.2011. 06.036

57. Kumari A, Kakkar P (2012) Lupeol prevents acetaminophen-induced in vivo hepatotoxicity by altering the $\mathrm{Bax} / \mathrm{BCl}-2$ and oxidative stress-mediated mitochondrial signaling cascade. Life Sci 90:561-570. https://doi.org/10.101 6/j.lfs.2012.01.012

58. Ghasemian M, Owlia S, Owlia MB (2016) Review of anti-inflammatory herbal medicines. Adv Pharm Sci 2016:1-11

59. Jeong G, Byun E, Li B, Lee D, An R, Kim Y (2010) Neuroprotective effects of constituents of the root bark of Dictamnus dasycarpus in mouse hippocampal cells. Arch Pharm Res 33:1269-1275. https://doi.org/10.1007/ s12272-010-0818-9

60. Yoon JS, Sung SH, Kim YC (2008) Neuroprotective limonoids of root bark of Dictamnus dasycarpus. J Nat Prod 71:208-211. https://doi.org/10.1021/ np0705880

61. Li H, Li Y, Wang X-B, Pang T, Zhang L-Y, Luo J, Kong L-Y (2015) Mexicanolide limonoids with in vitro neuroprotective activities from seeds of Khaya. RSC Adv 5:40465-40474. https://doi.org/10.1039/c5ra05006e

62. Tian X, Li H, An F, Li R, Zhou M, Yang M, Kong L, Luo J (2017) New structurally diverse limonoids from the seeds of Khaya senegalensis. Planta Med 83:341-350. https://doi.org/10.1055/s-0042-117114

63. Paritala V, Chiruvella KK, Thammineni C, Gopal R, Mohammed A (2015) Phytochemicals and antimicrobial potentials of Mahogany family. Rev Bras Farm 25:61-83. https://doi.org/10.1016/j.bjp.2014.11.009

64. Aboutabl EA, El-Souda SS, Maamoun AA, Hashem FA, Moharam ME (2015) UPLC/Tandem mass and antimicrobial activity of Khaya senegalensis (A.Juss.). An la Real Acad Nac Farm 81:258-265

65. Abdelgaleil SAM, Hashinaga F, Nakatani M (2005) Antifungal activity of limonoids from Khaya ivorensis. Pest Manag Sci 61:186-190. https://doi.org/1 $0.1002 / p s .978$

66. Yuan C-M, Zhang Y, Tang G-H, Di Y-T, Cao M-M, Wang X-Y, Zuo G-Y, Li S-L, Hua H-M, He H-P, Hao X-J (2013) Khayseneganins A-H, limonoids from Khaya senegalensis. J Nat Prod 76:327-333. https://doi.org/10.1021/ np3006919
67. Croteau R, Kutchan TM, Lewis NG (2000) Secondary metabolites. American Society of Plant Pathologists, New York

68. Koul O (2008) Phytochemicals and insect control : An antifeedant approach. CRC Crit Rev Plant Sci 27:1-24. https://doi.org/10.1080/07352 680802053908

69. Ibrahim MA, Islam MS (2014) Butanol fraction of Khaya senegalensis root modulates $\beta$-cell function and ameliorates diabetes-related biochemical parameters in a type 2 diabetes rat model. J Ethnopharmacol 154:832-838. https://doi.org/10.1016/j.jep.2014.05.011

70. Kayser O, Abreu PM (2001) Antileishmania and immunostimulating activities of two dimeric proanthocyanidins From Khaya senegalensis. Pharm Biol 39: 284-288

71. Ademola IO, Fagbemi BO, Idowu SO (2004) Evaluation of the anthelmintic activity of Khaya senegalensis extract against gastrointestinal nematodes of sheep: In vitro and in vivo studies. Vet Parasitol 122:151-164. https://doi. org/10.1016/j.vetpar.2004.04.001

72. Muraina IA, Gotep JG, Tanko JT, Onyiche TGE, Aladelokun OB, Dapuliga CC, Forcados GE, Ozele N, Samuel AL, Oladipo OO, Akanbi OB, Okewole PA, Ahmed MS (2020) Anticoccidial effects of Khaya senegalensis aqueous stem bark extract on broiler chickens experimentally infected with Eimeria species. Tropl Anim Health Prod 52:1249-1255. https://doi.org/10.1007/s112 50-019-02125-4

73. Elisha IL, Makoshi MS, Makama S, Dawurung CJ, Offiah NV, Gotep JG, Oladipo OO, Shamaki D (2013) Antidiarrheal evaluation of aqueous and ethanolic stem bark extracts of Khaya senegalensis A. Juss (Meliaceae) in Albino Rats. Pakistan Vet J 33:32-36

74. Suleiman MM, Tauheed M, Babandi JS (2013) An in vivo experimental trial to determine the efficacy of stem bark extract of Khaya senegalensis A. Juss (Meliaceae) for treating gastric ulcer in rat. Int J Med Arom Plants 3:352-361

75. Tijjani I, Abdullahi N (2020) Evaluation of Mahogany (Khaya senegalensis L.) stembark powder for the management of root-knot nematode (Meloidogyne spp.) on cowpea (Vigna unguiculata (L.)Walp). FUDMA J Sci 4: $76-84$

76. Sulaiman FA, lyiola OA, Anifowoshe TA, Sulaiman AA, Bello OK, Akinyele TJ, Jimoh AM, Maimako RF, Otohinoyi DA, Osemwegie OO, Adeyemi OS (2020) Anti-trypanosoma and toxicity potential of the extracts of Acacia nilotica, Bombax buonopozense and Khaya senegalensis. Adv Tradit Med:1-8. https:// doi.org/10.1007/s13596-020-00438-6

77. Nuhu A, Mukhtar MD, Bukar A (2019) Antidermatophytic activity of stem bark extracts of Khaya senegalensis. Niger J Microbiol 33:4705-4712

78. Monon K, Youssouf Zanga T, Fernique KK, Abdoulaye T, Konan Henri Joel KK, Karamoko O, Adama C (2019) Phytochimic study, antioxidant activity and nutritional interest of extracts from leaves of Khaya senegalensis (Desr) A. Juss (Meliaceae) collected in the Northern Cote d'ivoire. J Pharm Res Int 31:1-10. https://doi.org/10.9734/jpri/2019/v31i630315

79. Atawodi SE, Idakwo P (2009) Assessment of the polyphenol profile and antioxidant properties of leaves, stem and root barks of Khaya senegalensis (Desv.) A.Juss. Electron J Biol 5:80-84

80. Sandrine E, Christophe M, Ernestine N, George E-O, Vernyuy T, Barthelemy N (2016) cytoprotective and antioxidant properties of the stem bark aqueous extract of Khaya grandifoliola (Meliaceae) in Rats. Br J Pharm Res 9:1-11. https://doi.org/10.9734/bjpr/2016/20067

81. Hashem FA, Aboutabl EA, El SS, Moharam M, Mammoun AA, Shabana M (2013) Desmutagenic and antimutagenic potential of phenolics from Khaya grandifoliola ( C . DC .), Meliaceae. Egypt Pharm J 12:148-154. https://doi. org/10.4103/1687-4315.124018

82. Falodun A, Siraj R, Irfan M (2009) Chemical composition and insecticidal activity of volatile oil of Khaya grandifoliola. Med Aromat Plant Sci Biotechnol 3:61-63

83. Eisa Al, Elamin T, Elfaki M, Abdellah MA, Mohammed IA (2019) Molluscicidal activity of Khaya grandifoliola extracts against freshwater snails in Khartoum State- Sudan. Int J Acad Heal Med Res 3:29-31

84. Kengne FM, Kemegne MTS, Mangoua MFK, Obadiah K, Yunga ST, Mbacham WF, Leke RGF, Boudjeko T (2018) Evaluation of in vitro antioxidant and immunomodulatory activities of polysaccharide fractions of Khaya grandifoliola C . D . C (Welw) stem bark and Cryptolepis sanguinolenta (Lindl.) Schltr leaves. Afr J Biotechnol:1-9

85. Suleiman MM, Bagla V, Naidoo V, Eloff JN (2010) Evaluation of selected South African plant species for antioxidant, antiplatelet, and cytotoxic activity. Pharm Biol 48:643-650. https://doi.org/10.3109/1388020090322 9114 
86. Tsana R, Mafo M, Ottou M, Sidjui LS, Nnanga N (2019) Antimicrobial and antioxidant activities of ethanolic stem bark and root extracts of Khaya ivorensis A Chev. (Meliaceae). J Pharmacogn Phytochem 8:1393-1397

87. Wahedi J, Oaya C (2020) Termicidal activity of Azadirachta indica and Khaya ivorensis extracts on subterranean termites in Mubi, Nigeria. J Entomol Zool Stud 8:1519-1523

88. Asadi-Samani M, Kafash-Farkhad N, Azimi N, Fasihi A, Alinia-Ahandani E, Rafieian-Kopaei M (2015) Medicinal plants with hepatoprotective activity in Iranian folk medicine. Asian Pac J Trop Biomed 5:146-157. https://doi.org/1 0.1016/S2221-1691(15)30159-3

\section{Publisher's Note}

Springer Nature remains neutral with regard to jurisdictional claims in published maps and institutional affiliations.

\section{Submit your manuscript to a SpringerOpen ${ }^{\circ}$ journal and benefit from:}

- Convenient online submission

- Rigorous peer review

- Open access: articles freely available online

- High visibility within the field

- Retaining the copyright to your article

Submit your next manuscript at $\boldsymbol{\nabla}$ springeropen.com 